\title{
Parasite infection is associated with Kaposi's sarcoma associated herpesvirus (KSHV) in Ugandan women
}

\author{
Katie Wakeham ${ }^{1,2^{*}}$, Emily L Webb ${ }^{3}$, Ismail Sebina ${ }^{1}$, Lawrence Muhangi ${ }^{1}$, Wendell Miley ${ }^{4}$, W Thomas Johnson ${ }^{2}$, \\ Juliet Ndibazza', Alison M Elliott ${ }^{1,5+}$, Denise Whitby ${ }^{4+}$ and Robert Newton ${ }^{2,6+}$
}

\begin{abstract}
Background: Immune modulation by parasites may influence susceptibility to bacteria and viruses. We examined the association between current parasite infections, HIV and syphilis (measured in blood or stool samples using standard methods) and antibodies against Kaposi's sarcoma herpesvirus (KSHV), measured by ELISA, in 1915 stored plasma samples from pregnant women in Entebbe, Uganda.

Results: Seroprevalence of KSHV was higher in women with malaria parasitaemia ( $73 \%$ vs $60 \% p=0.01$ ), hookworm (67\% vs $56 \% p=0.001)$ and Mansonella perstans (69\% vs $59 \% p=0.05)$; seroprevalence increased with increasing intensity of hookworm infection ( $p<0.001$ [trend]). No associations were found for HIV, five other parasites or active syphilis. These effects were not explained by socioeconomic status or education.
\end{abstract}

Conclusions: Specific parasite infections are associated with presence of antibodies against KSHV, perhaps mediated via their effect on immune function.

\section{Background}

Infection with KSHV is the underlying cause of Kaposi's sarcoma (KS), although it may not be sufficient [1]. Immune suppression, such as that caused by human immunodeficiency virus (HIV), significantly increases the risk of KS among KSHV infected people and is associated with increased viral load and viral shedding [2-8]. Among people without HIV infection or other forms of overt immune suppression, geographic and temporal variation in the incidence of KS and in the prevalence of KSHV suggest that cofactors may be important in facilitating both transmission and disease [9-18]. Whether cofactors act directly or via effects on the immune system is unclear [19].

Many environmental co-factors for KSHV transmission and disease have been suggested, including volcanic soils [20], limestone [21] and 'oncoweeds' - that is plants with

\footnotetext{
* Correspondence: katiewakeham@gmail.com

+ Contributed equally

${ }^{1}$ Co-infections Studies Programme, Medical Research Council/Uganda Virus Research Institute Uganda Research Unit on AIDS, PO Box 49, Entebbe, Uganda

Full list of author information is available at the end of the article
}

carcinogenic properties or the ability to reactivate KSHV in vitro - although epidemiologic evidence of a role for these agents remains scant [22]. Ecological studies in the Mediterranean area found that eradication of mosquitoes and other blood sucking arthropods was associated with declines both in the prevalence of KSHV and in the incidence of KS [9-14,18,23]. The 'promoter arthropod hypothesis' suggests that insect blood feeding increases KSHV transmission through viral reactivation and KS through inflammatory mechanisms associated with the bite $[11,14]$.

Studies of KS in Africa have identified risk factors for KS that might be common to risk of certain parasites, such as exposure to water, high rainfall and walking barefoot [15,24-26]. Previously reported risk factors for KSHV, such as use of surface rather than piped water, may also be consistent with increased exposure to parasites [27]. Ecological associations between malaria and KSHV or KS in Africa are inconclusive [15]. Only one study has attempted to measure parasite burden among cases with KS and controls; KS patients had a higher carriage of certain intestinal helminths than did controls [28].

\section{() Biomed Central}


Parasites impact on immune function [29,30] and could, therefore, modulate the host response to KSHV. The association between EBV (another gamma herpesvirus) and malaria is well documented [31-34]. Parasiterelated immune modulation may increase susceptibility to KSHV infection and may also be associated with increased viral shedding and transmission, leading to an increased prevalence of $\mathrm{KSHV}$ infection and increased incidence of KS. We tested the hypothesis that parasites may be associated with KSHV by examining associations between current parasite infections and presence of antibodies against KSHV.

\section{Methods}

The investigation was conducted within an existing study in Uganda - the Entebbe Mother and Baby Study (EMaBS) - a large on-going double blind randomised placebo controlled trial designed to determine the impact of helminth infections and their treatment on vaccine responses and infectious disease outcomes. Detailed information about the study design has been reported elsewhere [35]. Briefly, consenting pregnant women resident in Entebbe and Katabi were recruited from the government funded antenatal clinic at Entebbe hospital, Uganda. Blood samples were obtained by venepuncture, and processed for syphilis, HIV serology, CD4 count and for examination for malaria parasites and Mansonella perstans. A stool sample was obtained for examination for intestinal helminths. Of note, women were apparently well on the day of enrollment, so infections identified were essentially asymptomatic. Information was collected on clinical and socio-demographic variables and socioeconomic status was defined according to a composite variable comprising information on several relevant factors [35].

Maternal plasma samples from the enrolment visitstored at $-80^{\circ} \mathrm{C}$ at the Uganda Virus Research Institute (UVRI), Entebbe, Uganda - were identified for 1915 women. KSHV serologic testing was based on ELISA for recombinant proteins to K8.1, a KSHV structural glycoprotein expressed during lytic infection, and for ORF 73, a nuclear antigen expressed during latency as previously described [36,37]. Each ELISA plate contained three positive and three negative controls for quality control and cut-off calculation. Both K8.1 and ORF 73 assay have high performance accuracy with a sensitivity of $98.78 \%$ and $89.02 \%$ respectively and specificity of $98.79 \%$ and $97.57 \%$ respectively [36]. The ELISAs were performed at the Uganda Virus Research Institute (UVRI) by the study lead and a technician, both of whom were blinded to patient details. The two assays were used to define evidence of KSHV - individuals were considered to be seropositive if they were positive to either assay and negative if both ELISA assays were negative. The assays were transferred to UVRI from the Viral Oncology Section (VOS), National Cancer Institute (NCI), USA and analysis of the positive and negative controls showed comparable performance at NCI and UVRI. The geometric mean optical density (OD) of the ORF 73 positive and negative controls was 2.50 and 0.04 respectively at VOS, NCI and 2.62 and 0.06 respectively at UVRI. The K8.1 positive and negative controls were 2.23 and 0.10 at NCI and 2.22 and 0.06 at UVRI. Analysis of 375 samples tested in duplicate at both VOS, $\mathrm{NCI}$ and UVRI resulted in Kappa values of 0.89 for the K8.1 ELISA and 0.86 for the ORF 73 ELISA.

For parasite intensities, hookworm was measured by egg counts in stool and catogorised as light $(<1,000$ eggs per gram (epg) of stool), moderate (1,000 to 3,999 epg) and heavy infection ( $\geq 4,000$ epg) [35,38]. The intensity of malaria infection was categorised as being below ("low") or above ("high") the median parasite count, per 200 white blood cells. For microfilariae, tertiles of the number of filaria per millilitre of blood were used to categorise into low, medium and high infection intensity.

Data were analysed using Stata11SE (StataCorp LP, College Station, Texas, USA). Potential associations between KSHV seropositivity and each potential risk factor were estimated using the Pearson chi-squared test or Fisher's exact test where expected numbers were small. Odds ratios (ORs) and 95\% confidence intervals (CIs) were calculated using logistic regression modeling controlling for age and other possible confounders. The possibility of multiple parasite infections increasing risk of KSHV seropositivity more or less than expected under a multiplicative model was assessed by fitting terms for interactions between parasites in the logistic regression model. The agreement between K8.1 and ORF73 ELISA assays was assessed formally by calculating a Kappa statistic. All p values were 2 -sided and we considered $\mathrm{p}<0.05$ to be statistically significant.

\section{Results and Discussion}

The median age of women in the study was 23 years (IQR 19-27); most were in the third trimester of pregnancy (54\% (1032/1915) with 46\% (879/1915) in the second). The seroprevalence of HIV was $10 \%$ (193/1915) and the median CD4 count among those who were seropositive was 551 (IQR 368-796). The highest level of educational attainment reached by the majority of women was primary (50\% [961/1911]), with 62\% (1191/1915) describing themselves as unemployed or housewives and 82\% (1561/1905) reporting a personal income of less than 30,000 Ugandan Shillings (approx. \$12USD) per month. The prevalence of antibodies to K8.1 was $41 \%$ and to ORF 73 was $52 \%$. $32 \%$ of women were seropositive to both antigens and $61 \%$ had antibodies to either ORF 73 and/or K8.1. There was moderate concordance between latent KSHV ORF 73 and lytic 
KSHV K8.1 assays in detecting KSHV seropositivity ( $\mathrm{k}=$ $0.43)$, consistent with previous studies $[37,39]$. Prevalence of antibodies did not change significantly with age, although the age range of study participants was relatively narrow. Previous studies of women in a similarly narrow age range in Africa have showed little or no association with age $[27,37,39,40]$. As expected, prevalence decreased with increasing maternal education and household socioeconomic status [27]

Common infections among the participants were hookworm (44\%), Mansonella perstans (21\%), Schistosoma mansoni (18\%), asymptomatic Plasmodium falciparum parasitaemia (10\%) and HIV (10\%). The prevalence of antibodies to K8.1, ORF 73, both antigens and either antigen was $41 \%, 52 \%, 32 \%$ and $61 \%$ respectively. Unadjusted ORs for the association of infections (including eight current parasitic infections), socio-demographic and behavioral factors with antibodies against KSHV are shown in Table 1. In Table 2, the variables found to be associated with KSHV serostatus have been examined again with adjustment for each other. Seropositivity to KSHV was significantly associated with malaria parasitaemia, hookworm and Mansonella perstans. The prevalence of antibodies to KSHV increased with increasing intensity of hookworm infection ( $\mathrm{p}<0.001$ [trend]; as measured by egg counts in stool), from $56 \%$ among those with no infection to $67 \%$ in those with light/moderate infection (12 - the limit of detection - to 3,999 eggs per gram (epg) of stool) to $72 \%$ in those with heavy infection ( $\geq 4,000$ epg); no consistent trends were observed for malaria parasite density or Mansonella perstans intensity, but most infections were light (Table 3).

Mode of KSHV transmission is yet to be fully elucidated, but high acquisition rates during childhood imply a nonsexual route $[7,27,37,40-49]$. In studies of mother-child pairs $[37,40,50]$, the impact of HIV on KSHV seropositivity is unclear with some studies reporting a positive impact [37] and others reporting borderline or null association $[40,50]$. We observed no statistically significant association between HIV and KSHV seropositivity. There was no association between KSHV seropositivity and CD4 count in HIV infected women ( $\mathrm{p}=0.13)$. The lack of association with syphilis is consistent with previous studies reporting no association with KSHV and markers of sexual behavior

Table 1 Crude associations with antibodies against KSHV and sociodemographic and clinical risk factors among Ugandan women

\begin{tabular}{|c|c|c|c|}
\hline Factor & Prevalence of women KSHV seropositive* & OR $(95 \% \mathrm{Cl})$ & $\mathrm{P} * *$ \\
\hline \multicolumn{4}{|l|}{ Age } \\
\hline 14-19 years & $65 \%(288 / 443)$ & 1 & \\
\hline 20-24 years & $62 \%(446 / 717)$ & $0.89(0.70-1.14)$ & \\
\hline $25-29$ years & $56 \%(252 / 444)$ & $0.71(0.54-0.93)$ & \\
\hline 30-34 years & $58 \%(125 / 216)$ & $0.74(0.53-1.03)$ & \\
\hline$>=35$ years & $55 \%(52 / 94)$ & $0.67(0.43-1.05)$ & 0.007 [trend] \\
\hline \multicolumn{4}{|c|}{ Maternal education } \\
\hline None & $74 \%(50 / 68)$ & 1 & \\
\hline Primary & $64 \%(617 / 960)$ & $0.65(0.37-1.12)$ & \\
\hline Senior & $59 \%(418 / 713)$ & $0.51(0.29-0.89)$ & \\
\hline Tertiary & $45 \%(76 / 169)$ & $0.29(0.16-0.55)$ & $<0.001$ (trend) \\
\hline \multicolumn{4}{|l|}{ Household SES*** } \\
\hline 1 (lowest) & $69 \%(75 / 109)$ & 1 & \\
\hline 2 & $71 \%(112 / 158)$ & $1.10(0.65-1.88)$ & \\
\hline 3 & $64 \% 369 / 581)$ & $0.79(0.51-1.22)$ & \\
\hline 4 & $58 \% 310 / 531)$ & $0.64(0.41-0.99)$ & \\
\hline 5 & $57 \%(222 / 389)$ & $0.60(0.38-0.95)$ & \\
\hline 6 (highest) & $50 \%(55 / 111)$ & $0.45(0.26-0.77)$ & $<0.001$ [trend] \\
\hline \multicolumn{4}{|l|}{ HIV } \\
\hline Negative & $60 \%(1033 / 1721)$ & 1 & \\
\hline Positive & $67 \%(130 / 193)$ & $1.38(1.00-1.89)$ & 0.04 \\
\hline \multicolumn{4}{|l|}{ Malaria parasites } \\
\hline No & $60 \%(1010 / 1697)$ & 1 & \\
\hline Yes & $73 \%(135 / 185)$ & $1.84(1.31-2.58)$ & $<0.001$ \\
\hline \multicolumn{4}{|l|}{ Active syphilis } \\
\hline No & $61 \%$ 1110/1833) & 1 & \\
\hline Yes & $68 \%(52 / 76)$ & $1.41(0.86-2.31)$ & 0.25 \\
\hline
\end{tabular}


Table 1 Crude associations with antibodies against KSHV and sociodemographic and clinical risk factors among Ugandan women (Continued)

\begin{tabular}{|c|c|c|c|}
\hline \multicolumn{4}{|l|}{ Hookworm } \\
\hline No & $56 \%(594 / 1070)$ & 1 & \\
\hline Yes & $67 \%(562 / 836)$ & $1.64(1.36-1.98)$ & $<0.001$ \\
\hline \multicolumn{4}{|c|}{ Mansonella perstans } \\
\hline No & $59 \%(884 / 1508)$ & 1 & \\
\hline Yes & $69 \%(277 / 402)$ & $1.55(1.23-1.96)$ & $<0.001$ \\
\hline \multicolumn{4}{|c|}{ Schistosoma mansoni } \\
\hline No & $61 \%(952 / 1568)$ & 1 & \\
\hline Yes & $60 \%(204 / 338)$ & $1.0(0.78-1.25)$ & 0.90 \\
\hline \multicolumn{4}{|c|}{ Strongyloides stercoralis } \\
\hline No & $61 \%(1007 / 1665)$ & 1 & \\
\hline Yes & $63 \%(144 / 230)$ & $1.10(0.82-1.46)$ & 0.54 \\
\hline \multicolumn{4}{|c|}{ Trichuris trichiura } \\
\hline No & $60 \%(1044 / 1739)$ & 1 & \\
\hline Yes & $67 \%(112 / 167)$ & $1.36(0.97-1.90)$ & 0.07 \\
\hline \multicolumn{4}{|c|}{ Ascaris lumbricoides } \\
\hline No & $61 \%(1125 / 1859)$ & 1 & \\
\hline Yes & $66 \%(31 / 47)$ & $1.27(0.69-2.33)$ & 0.45 \\
\hline \multicolumn{4}{|c|}{ Trichostrongylus species } \\
\hline No & $61 \%(1149 / 1887)$ & 1 & \\
\hline Yes & $37 \%(7 / 19)$ & $0.38(0.15-0.96)$ & 0.03 \\
\hline \multicolumn{4}{|c|}{ Use of mosquito spray in the home } \\
\hline No & $62 \%(942 / 1510)$ & 1 & \\
\hline Yes & $55 \%(219 / 400)$ & $0.73(0.58-0.90)$ & 0.005 \\
\hline \multicolumn{4}{|c|}{ Use of bed net } \\
\hline No & $61 \%(574 / 952)$ & 1 & \\
\hline Yes & $60 \%(587 / 959)$ & $1.04(0.87-1.25)$ & 0.68 \\
\hline \multicolumn{4}{|c|}{ Walk barefoot } \\
\hline Yes & $61 \%(925 / 1505)$ & 1 & \\
\hline No & $58 \%(236 / 407)$ & $1.15(0.92-1.44)$ & 0.20 \\
\hline
\end{tabular}

* Individuals were considered KSHV positive if they had a positive ORF 73 and/or K8.1 ELISA. Participants were considered negative if both ELISAs were negative. ** All estimated using Chi-squared test except for Trichostrongylus species which was estimated using a Fishers exact test. All tests of statistical significance two sided.

*** Socio-economic status

$[37,47,51,52]$. In unadjusted analyses, the use of insecticide in the home was associated with a lower prevalence of antibodies against KSHV ( $\mathrm{p}=0.005)$ although use of a bed net and walking barefoot (a risk factor for hookworm infection) was not. Effects of increasing numbers of infections on KSHV seropositivity combined multiplicatively; there were no interactions between the effects of HIV, malaria parasitaemia, hookworm or Mansonella perstans on KSHV infection (results not shown). KSHV seropositivity was not associated with trimester or pregnancy duration as measured in months. The results for ORF 73 and K8.1 separately, did not materially differ.

This study has a number of important limitations. It is possible that associations arose as a result of residual confounding by socio-economic status (SES), although adjustment for certain markers of SES had no effect on the findings. Furthermore, the work was cross sectional and so associations identified should be confirmed in longitudinal studies. Also, the study participants were pregnant and pregnancy itself may modulate immune function. However, since all comparisons were internal within the study (i.e. comparing one group of pregnant women with another), it is difficult to see how this could have impacted on the results.

\section{Conclusions}

The findings reported here provide evidence of an association between specific parasites and presence of antibodies against KSHV. Specific parasite infections may increase KSHV replication or cause reactivation, thereby increasing the likelihood of detecting antibodies against KSHV. Alternatively, specific parasites may increase susceptibility to infection - we cannot, in this study, distinguish between these two possibilities. Co-factors for 
Table 2 Adjusted associations with antibodies against KSHV and sociodemographic and clinical risk factors among Ugandan women.

\begin{tabular}{|c|c|c|}
\hline \multirow[b]{2}{*}{ Factor ${ }^{* *}$} & \multicolumn{2}{|c|}{ KSHV seropositive* } \\
\hline & OR $(95 \% \mathrm{Cl})$ & $\mathrm{P}^{* * *}$ \\
\hline Age & 1 & \\
\hline Trend OR & $0.94(0.86-1.02)$ & 0.14 \\
\hline Maternal education & 1 & \\
\hline Trend OR & $0.79(0.69-0.91)$ & 0.001 \\
\hline Household SES**** & 1 & \\
\hline Trend OR & $0.90(0.83-0.98)$ & 0.01 \\
\hline \multicolumn{3}{|l|}{ HIV status } \\
\hline Negative & 1 & \\
\hline Positive & $1.35(0.97-1.89)$ & 0.08 \\
\hline \multicolumn{3}{|l|}{ Malaria parasites } \\
\hline No & 1 & \\
\hline Yes & $1.60(1.12-2.27)$ & 0.01 \\
\hline \multicolumn{3}{|l|}{ Hookworm } \\
\hline No & 1 & \\
\hline Yes & $1.40(1.14-1.71)$ & 0.001 \\
\hline \multicolumn{3}{|l|}{ Mansonella perstans } \\
\hline No & 1 & \\
\hline Yes & $1.29(1.00-1.65)$ & 0.05 \\
\hline
\end{tabular}

* Individuals were considered KSHV positive if they had a positive ORF 73 and/or K8.1 ELISA. Participants were considered negative if both ELISAs were negative,

${ }^{* *}$ All factors are adjusted for each other

${ }^{* * *}$ All tests of statistical significance two sided.

**** Socio-economic status
KSHV transmission and disease have been sought to explain the elevated prevalence of KSHV and incidence of KS in sub-Saharan Africa. Data presented here suggest that parasites may constitute one such co-factor. Further epidemiological and laboratory studies are needed to fully understand the role of parasites as a risk factor for infection with KSHV.

\section{Ethical approval}

Ethical approval for this study was obtained from three bodies: Uganda Virus Research Institute Science and Ethics Committee, Entebbe, Uganda; Uganda National Council for Science and Technology; and the University of York, UK.

\title{
Acknowledgements
}

Wellcome Trust as a PhD Training Fellowship held by KW (grant number 090132), a Wellcome Trust Senior Fellowship held by AME (grant number 064693) and funded in part by the Intramural Program of the National Cancer Institute, National Institutes of Health, Department of Health and Human Services (contract HHSN261200800001E). Wellcome Trust is a UK registered charity No.210183. We thank all the participants and the staff of the Entebbe Mother and Baby Study and the staff of the laboratory and statistics departments of the Medical Research Council/Uganda Virus Research Institute Uganda Research Unit on AIDS who made this study possible.

\begin{abstract}
Author details
${ }^{1}$ Co-infections Studies Programme, Medical Research Council/Uganda Virus Research Institute Uganda Research Unit on AIDS, PO Box 49, Entebbe, Uganda. ${ }^{2}$ Epidemiology and Genetics Unit, Department of Health Sciences, Area 3 Seebohm Rowntree Building, University of York, York, YO10 5DD, UK. ${ }^{3}$ Department of Infectious Disease Epidemiology, London School of Hygiene and Tropical Medicine, Keppal Street, London, WC1E 7HT, UK. "Viral Oncology Section, AIDS and Cancer Virus Program, SAIC Frederick, National Cancer Institute, PO Box B, Frederick, MD 21702, USA. ${ }^{5}$ Department of Clinical Research, London School of Hygiene and Tropical Medicine, Keppal Street, London, WC1E 7HT, UK. ${ }^{6}$ Hull York Medical School, University of York Heslington, YO10 5DD, UK.
\end{abstract}

Table 3 Crude associations with antibodies against KSHV and intensity of parasite infection in Uganda women.

\begin{tabular}{|c|c|c|c|}
\hline Infection & Prevalence of women KSHV seropositive* & OR $(95 \% \mathrm{Cl})$ & $P^{* *}$ \\
\hline \multicolumn{4}{|l|}{ Hookworm } \\
\hline Uninfected & $56 \%(594 / 1070)$ & 1 & \\
\hline Light & $67 \%(478 / 714)$ & $1.62(1.33-1.98)$ & \\
\hline Moderate & $67 \%(61 / 91)$ & $1.62(1.04-2.56)$ & \\
\hline Heavy & $72 \%(23 / 32)$ & $2.05(0.94-4.47)$ & $<0.001$ [trend] \\
\hline \multicolumn{4}{|c|}{ Malaria parasites } \\
\hline No & $40 \%(687 / 1697)$ & 1 & \\
\hline Low & $75 \%(68 / 91)$ & $2.01(1.24-3.26)$ & \\
\hline High & $66 \%(81 / 123)$ & $1.31(0.89-1.93)$ & $0.02[$ trend] \\
\hline \multicolumn{4}{|c|}{ Mansonella perstans } \\
\hline Uninfected & $59 \%(884 / 1508)$ & 1 & \\
\hline Light & $69 \%(98 / 142)$ & $1.57(1.09-2.28)$ & \\
\hline Moderate & $74 \%(68 / 92)$ & $2.00(1.24-3.22)$ & \\
\hline Heavy & $66 \%(111 / 169)$ & $1.35(0.97-1.89)$ & $0.02[$ trend $]$ \\
\hline
\end{tabular}

* Individuals were considered KSHV positive if they had a positive ORF 73 and/or K8.1 ELISA. Participants were considered negative if both ELISAs were negative.

** All estimated using Chi-squared test. All tests of statistical significance two sided. 


\section{Authors' contributions}

KW conceived and coordinated the study, carried out the KSHV ELISA assays, performed the statistical analysis and drafted the manuscript, ELW performed the statistical analysis and helped to draft the manuscript, IS carried out KSHV ELISA assays, LM managed the study database, WM set up, validated and carried out the KSHV ELISA assays and helped to draft the manuscript, WTM helped with statistical analysis and drafting the manuscript, JN was project leader for the EMaBS cohort, AME is principle investigator for the EMaBS cohort, conceived the study and helped with statistical analysis and drafting the manuscript, DW is head of VOS, NCl, conceived the study and drafted the manuscript and RN drafted the manuscript. All authors have read and approved the final manuscript.

\section{Competing interests}

The authors declare that they have no competing interests.

Received: 12 July 2011 Accepted: 30 September 2011

Published: 30 September 2011

\section{References}

1. Bouvard V, Baan R, Straif K, Grosse Y, Secretan B, El Ghissassi F, BenbrahimTallaa L, Guha N, Freeman C, Galichet L, Cogliano V: A review of human carcinogens-Part B: biological agents. Lancet Oncol 2009, 10:321-322.

2. Engels EA, Biggar RJ, Marshall VA, Walters MA, Gamache CJ, Whitby D, Goedert JJ: Detection and quantification of Kaposi's sarcoma-associated herpesvirus to predict AIDS-associated Kaposi's sarcoma. AIDS 2003, 17:1847-1851.

3. Laney AS, Dollard SC, Jaffe HW, Offermann MK, Spira TJ, Gunthel CJ, Pellett PE, Cannon MJ: Repeated measures study of human herpesvirus 8 (HHV-8) DNA and antibodies in men seropositive for both HHV-8 and HIV. AIDS 2004, 18:1819-1826.

4. Laney AS, Cannon MJ, Jaffe HW, Offermann MK, Ou CY, Radford KW, Patel MM, Spira TJ, Gunthel CJ, Pellett PE, Dollard SC: Human herpesvirus 8 presence and viral load are associated with the progression of AIDSassociated Kaposi's sarcoma. AIDS 2007, 21:1541-1545.

5. Merat R, Amara A, Lebbe C, de The H, Morel P, Saib A: HIV-1 infection of primary effusion lymphoma cell line triggers Kaposi's sarcomaassociated herpesvirus (KSHV) reactivation. Int J Cancer 2002, 97:791-795.

6. Bagni R, Whitby D: Kaposi's sarcoma-associated herpesvirus transmission and primary infection. Curr Opin HIV AIDS 2009, 4:22-26.

7. Sitas F, Carrara H, Beral V, Newton R, Reeves G, Bull D, Jentsch U, PacellaNorman R, Bourboulia D, Whitby D, Boshoff C, Weiss R: Antibodies against human herpesvirus 8 in black South African patients with cancer. $N$ Engl J Med 1999, 340:1863-1871.

8. Grundhoff A, Ganem D: Inefficient establishment of KSHV latency suggests an additional role for continued lytic replication in Kaposi sarcoma pathogenesis. J Clin Invest 2004, 113:124-136.

9. Ascoli V, Belli S, Benedetti M, Trinca S, Ricci P, Comba P: High incidence of classic Kaposi's sarcoma in Mantua, Po Valley, Northern Italy (19891998). Br J Cancer 2001, 85:379-382.

10. Ascoli V, Facchinelli L, Valerio L, Zucchetto A, Dal Maso L, Coluzzi M: Distribution of mosquito species in areas with high and low incidence of classic Kaposi's sarcoma and seroprevalence for HHV-8. Med Vet Entomol 2006, 20:198-208.

11. Ascoli V, Senis G, Zucchetto A, Valerio L, Facchinelli L, Budroni M, Dal Maso L, Coluzzi M: Distribution of 'promoter' sandflies associated with incidence of classic Kaposi's sarcoma. Med Vet Entomol 2009, 23:217-225.

12. Ascoli V, Zambon P, Manno D, Guzzinati S, Zorzi M, Arca B, Costantini C, Coluzzi M: Variability in the incidence of classic Kaposi's sarcoma in the Veneto region, Northern Italy. Tumori 2003, 89:122-124.

13. Coluzzi M, Calabro ML, Manno D, Chieco-Bianchi L, Schulz TF, Ascoli V: Reduced seroprevalence of Kaposi's sarcoma-associated herpesvirus (KSHV), human herpesvirus 8 (HHV8), related to suppression of Anopheles density in Italy. Med Vet Entomol 2003, 17:461-464.

14. Coluzzi M, Manno D, Guzzinati S, Tognazzo S, Zambon P, Arca B, Costantini C, Ascoli V: The bloodsucking arthropod bite as possible cofactor in the transmission of human herpesvirus-8 infection and in the expression of Kaposi's sarcoma disease. Parassitologia 2002, 44:123-129.

15. Cook-Mozaffari P, Newton R, Beral V, Burkitt DP: The geographical distribution of Kaposi's sarcoma and of lymphomas in Africa before the AIDS epidemic. Br J Cancer 1998, 78:1521-1528.
16. Dedicoat M, Newton R: Review of the distribution of Kaposi's sarcomaassociated herpesvirus (KSHV) in Africa in relation to the incidence of Kaposi's sarcoma. Br J Cancer 2003, 88:1-3.

17. Dollard SC, Butler LM, Graves Jones AM, Mermin JH, Chidzonga M, Chipato T, Shiboski CH, Brander C, Mosam A, Kiepiela P, Hladik W, Martin JN: Substantial regional differences in human herpesvirus 8 seroprevalence in sub-saharan Africa: Insights on the origin of the "KS Belt". Int J Cancer 2010.

18. Tanzi E, Zappa A, Caramaschi F, Amendola A, Lasagna D, Gatti L, Ascoli V, Rezza G, Zanetti AR: Human herpesvirus type 8 infection in an area of Northern Italy with high incidence of classical Kaposi's sarcoma. J Med Virol 2005, 76:571-575.

19. Brown EE, Whitby D, Vitale F, Marshall V, Mbisa G, Gamache C, Lauria C, Alberg AJ, Serraino D, Cordiali-Fei P, Messina A, Goedert JJ: Virologic, hematologic, and immunologic risk factors for classic Kaposi sarcoma. Cancer 2006, 107:2282-2290.

20. Montesu MA, De Marco R, Cottoni F: Soil silicates and Kaposi's sarcoma in Sardinia. Lancet 1995, 346:1436-1437.

21. Ziegler JL: Endemic Kaposi's sarcoma in Africa and local volcanic soils. Lancet 1993, 342:1348-1351.

22. Whitby D, Marshall VA, Bagni RK, Miley WJ, McCloud TG, Hines-Boykin R, Goedert JJ, Conde BA, Nagashima K, Mikovits J, Dittmer DP, Newman DJ: Reactivation of Kaposi's sarcoma-associated herpesvirus by natural products from Kaposi's sarcoma endemic regions. Int J Cancer 2007 120:321-328.

23. Ascoli V, Facchinelli L, Valerio L, Manno D, Coluzzi M: Kaposi's sarcoma, human herpesvirus 8 infection and the potential role of promoterarthropod bites in northern Sweden. J Med Virol 2006, 78:1452-1455.

24. Ziegler JL, Newton R, Katongole-Mbidde E, Mbulataiye S, De Cock K, Wabinga H, Mugerwa J, Katabira E, Jaffe H, Parkin DM, Reeves G, Weiss R, Beral V: Risk factors for Kaposi's sarcoma in HIV-positive subjects in Uganda. AIDS 1997, 11:1619-1626.

25. Ziegler J, Newton R, Bourboulia D, Casabonne D, Beral V, Mbidde E, Carpenter L, Reeves G, Parkin DM, Wabinga H, Mbulaiteye S, Jaffe $H$ Weiss R, Boshoff C: Risk factors for Kaposi's sarcoma: a case-control study of HIV-seronegative people in Uganda. Int J Cancer 2003, 103:233-240.

26. Hutt MS: The epidemiology of Kaposi's sarcoma. Antibiot Chemother 1981, 29:3-11

27. Mbulaiteye SM, Biggar RJ, Pfeiffer RM, Bakaki PM, Gamache C, Owor AM, Katongole-Mbidde E, Ndugwa CM, Goedert JJ, Whitby D, Engels EA: Water, socioeconomic factors, and human herpesvirus 8 infection in Ugandan children and their mothers. J Acquir Immune Defic Syndr 2005, 38:474-479.

28. Lin CJ, Katongole-Mbidde E, Byekwaso T, Orem J, Rabkin CS, Mbulaiteye SM: Intestinal parasites in Kaposi sarcoma patients in Uganda: indication of shared risk factors or etiologic association. Am J Trop Med Hyg 2008, 78:409-412.

29. Maizels RM: Parasite immunomodulation and polymorphisms of the immune system. J Biol 2009, 8:62.

30. Maizels RM, Pearce EJ, Artis D, Yazdanbakhsh M, Wynn TA: Regulation of pathogenesis and immunity in helminth infections. J Exp Med 2009, 206:2059-2066

31. Moormann AM, Chelimo K, Sumba OP, Lutzke ML, Ploutz-Snyder R, Newton D, Kazura J, Rochford R: Exposure to holoendemic malaria results in elevated Epstein-Barr virus loads in children. J Infect Dis 2005, 191:1233-1238.

32. Moormann AM, Chelimo K, Sumba PO, Tisch DJ, Rochford R, Kazura JW: Exposure to holoendemic malaria results in suppression of Epstein-Barr virus-specific T cell immunosurveillance in Kenyan children. $J$ Infect Dis 2007, 195:799-808

33. Piriou E, Kimmel R, Chelimo K, Middeldorp JM, Odada PS, Ploutz-Snyder R, Moormann AM, Rochford R: Serological evidence for long-term EpsteinBarr virus reactivation in children living in a holoendemic malaria region of Kenya. J Med Virol 2009, 81:1088-1093.

34. Rainey JJ, Mwanda WO, Wairiumu P, Moormann AM, Wilson ML, Rochford R: Spatial distribution of Burkitt's lymphoma in Kenya and association with malaria risk. Trop Med Int Health 2007, 12:936-943.

35. Elliott AM, Kizza M, Quigley MA, Ndibazza J, Nampijja M, Muhangi L, Morison L, Namujju PB, Muwanga M, Kabatereine N, Whitworth JA: The impact of helminths on the response to immunization and on the incidence of infection and disease in childhood in Uganda: design of a randomized, double-blind, placebo-controlled, factorial trial of 
deworming interventions delivered in pregnancy and early childhood [ISRCTN32849447]. Clin Trials 2007, 4:42-57.

36. Mbisa GL, Miley W, Gamache CJ, Gillette WK, Esposito D, Hopkins R, Busch MP, Schreiber GB, Little RF, Yarchoan R, Ortiz-Conde BA, Labo N, Whitby D: Detection of antibodies to Kaposi's sarcoma-associated herpesvirus: a new approach using K8.1 ELISA and a newly developed recombinant LANA ELISA.J I Immunol Methods 2010, 356:39-46.

37. Malope BI, Pfeiffer RM, Mbisa G, Stein L, Ratshikhopha EM, O'Connell DL, Sitas F, MacPhail P. Whitby D: Transmission of Kaposi sarcoma-associated herpesvirus between mothers and children in a South African population. J Acquir Immune Defic Syndr 2007, 44:351-355.

38. Ndibazza J, Muhangi L, Akishule D, Kiggundu M, Ameke C, Oweka J, Kizindo R, Duong T, Kleinschmidt I, Muwanga M, Elliott AM: Effects of deworming during pregnancy on maternal and perinatal outcomes in Entebbe, Uganda: a randomized controlled trial. Clin Infect Dis 2010, 50:531-540.

39. de Sanjose S, Marshall V, Sola J, Palacio V, Almirall R, Goedert JJ, Bosch FX, Whitby D: Prevalence of Kaposi's sarcoma-associated herpesvirus infection in sex workers and women from the general population in Spain. Int J Cancer 2002, 98:155-158.

40. Dedicoat M, Newton R, Alkharsah KR, Sheldon J, Szabados I, Ndlovu B, Page T, Casabonne D, Gilks CF, Cassol SA, Whitby D, Schulz TF: Mother-tochild transmission of human herpesvirus-8 in South Africa. $J$ Infect Dis 2004, 190:1068-1075

41. Wawer MJ, Eng SM, Serwadda D, Sewankambo NK, Kiwanuka N, Li C, Gray RH: Prevalence of Kaposi sarcoma-associated herpesvirus compared with selected sexually transmitted diseases in adolescents and young adults in rural Rakai District, Uganda. Sex Transm Dis 2001, 28:77-81.

42. Olsen SJ, Chang Y, Moore PS, Biggar RJ, Melbye M: Increasing Kaposi's sarcoma-associated herpesvirus seroprevalence with age in a highly Kaposi's sarcoma endemic region, Zambia in 1985. AIDS 1998, 12:1921-1925.

43. Minhas V, Crabtree KL, Chao A, M'Soka TJ, Kankasa C, Bulterys M, Mitchell CD, Wood C: Early childhood infection by human herpesvirus 8 in Zambia and the role of human immunodeficiency virus type 1 coinfection in a highly endemic area. Am J Epidemiol 2008, 168:311-320

44. Mbulaiteye SM, Walters M, Engels EA, Bakaki PM, Ndugwa CM, Owor AM, Goedert JJ, Whitby D, Biggar RJ: High levels of Epstein-Barr virus DNA in saliva and peripheral blood from Ugandan mother-child pairs. I Infect Dis 2006, 193:422-426

45. Mbulaiteye SM, Pfeiffer RM, Engels EA, Marshall V, Bakaki PM, Owor AM, Ndugwa CM, Katongole-Mbidde E, Goedert JJ, Biggar RJ, Whitby D: Detection of kaposi sarcoma-associated herpesvirus DNA in saliva and buffy-coat samples from children with sickle cell disease in Uganda. J Infect Dis 2004, 190:1382-1386.

46. Mbulaiteye S, Marshall V, Bagni RK, Wang CD, Mbisa G, Bakaki PM, Owor AM, Ndugwa CM, Engels EA, Katongole-Mbidde E, Biggar RJ, Whitby D: Molecular evidence for mother-to-child transmission of Kaposi sarcoma-associated herpesvirus in Uganda and K1 gene evolution within the host. J Infect Dis 2006, 193:1250-1257.

47. Malope BI, MacPhail P, Mbisa G, MacPhail C, Stein L, Ratshikhopha EM, Ndhlovu L, Sitas F, Whitby D: No evidence of sexual transmission of Kaposi's sarcoma herpes virus in a heterosexual South African population. AIDS 2008, 22:519-526.

48. Klaskala W, Brayfield BP, Kankasa C, Bhat G, West JT, Mitchell CD, Wood C: Epidemiological characteristics of human herpesvirus-8 infection in a large population of antenatal women in Zambia. J Med Virol 2005, 75:93-100.

49. Butler LM, Dorsey G, Hladik W, Rosenthal PJ, Brander C, Neilands TB, Mbisa G, Whitby D, Kiepiela P, Mosam A, Mzolo S, Dollard SC, Martin JN: Kaposi sarcoma-associated herpesvirus (KSHV) seroprevalence in population-based samples of African children: evidence for at least 2 patterns of KSHV transmission. J Infect Dis 2009, 200:430-438.

50. Brayfield BP, Phiri S, Kankasa C, Muyanga J, Mantina H, Kwenda G, West JT, Bhat G, Marx DB, Klaskala W, Mitchell CD, Wood C: Postnatal human herpesvirus 8 and human immunodeficiency virus type 1 infection in mothers and infants from Zambia. J Infect Dis 2003, 187:559-568.

51. de Sanjose S, Mbisa G, Perez-Alvarez S, Benavente Y, Sukvirach S, Hieu NT, Shin HR, Anh PT, Thomas J, Lazcano E, Matos E, Herrero R, Munoz N, Molano M, Franceschi S, Whitby D: Geographic variation in the prevalence of Kaposi sarcoma-associated herpesvirus and risk factors for transmission. J Infect Dis 2009, 199:1449-1456.

52. Newton R, Ziegler J, Bourboulia D, Casabonne D, Beral V, Mbidde E, Carpenter L, Reeves G, Parkin DM, Wabinga H, Mbulaiteye S, Jaffe H, Weiss R, Boshoff C: The sero-epidemiology of Kaposi's sarcomaassociated herpesvirus (KSHV/HHV-8) in adults with cancer in Uganda. Int J Cancer 2003, 103:226-232.

doi:10.1186/1750-9378-6-15

Cite this article as: Wakeham et al:: Parasite infection is associated with Kaposi's sarcoma associated herpesvirus (KSHV) in Ugandan women. Infectious Agents and Cancer 2011 6:15.

\section{Submit your next manuscript to BioMed Central and take full advantage of:}

- Convenient online submission

- Thorough peer review

- No space constraints or color figure charges

- Immediate publication on acceptance

- Inclusion in PubMed, CAS, Scopus and Google Scholar

- Research which is freely available for redistribution

Submit your manuscript at www biomedcentral com/submit
Ciomed Central 